Board of Governors of the Federal Reserve System

\author{
International Finance Discussion Papers
}

Number 692

December 2000

\title{
CURRENT ACCOUNT ADJUSTMENT IN INDUSTRIALIZED COUNTRIES
}

\author{
Caroline L. Freund
}

NOTE: International Finance Discussion Papers are preliminary materials circulated to stimulate discussion and critical comment. References in publications to International Finance Discussion Papers (other than an acknowledgment that the writer has had access to unpublished material) should be cleared with the author or authors. Recent IFDPs are available on the Web at www.bog.frb.fed.us. 


\title{
CURRENT ACCOUNT ADJUSTMENT IN INDUSTRIALIZED COUNTRIES
}

\author{
Caroline L. Freund*
}

\begin{abstract}
This paper examines the dynamics of current account adjustment among industrialized countries. We identify twenty-five episodes in which a large sustained improvement in the current account occurred between 1980 and 1997. We find that a typical current account reversal begins when the current account deficit is about 5 percent of GDP, and that it is associated with slowing income growth and a 10-20 percent real depreciation. Real export growth, declining investment, and an eventual leveling off in both the net international investment position and the budget deficit-GDP ratio are also likely to be part of the adjustment. These results suggest that current account reversals in industrialized countries are largely a function of the business cycle.
\end{abstract}

Keywords: current account deficit, trade deficit, exchange rate adjustment, currency crises

${ }^{*}$ Economist in the International Finance Division of the Federal Reserve Board. I would like to thank David Bowman, Hali Edison, Joseph Gagnon, William Helkie, David Howard, Steven Kamin, Karen Johnson, Vince Reinhart, Charles Thomas, and Kei-Mu Yi for helpful comments and Helen Oliver for research assistance. Correspondence: Caroline Freund, International Finance Division, Federal Reserve Board, Washington D.C. 20551, e-mail: caroline.l.freund@ frb.gov. The views presented here are solely the responsibility of the author and should not be interpreted as reflecting the views of the Board of Governors of the Federal Reserve System or any other person associated with the Federal Reserve System. 


\section{Introduction}

How have large and growing current account deficits among industrialized countries been reversed in the recent past? To answer this question, we characterize how macro-variables adjust in conjunction with the current account, using data from twenty-five episodes in which a large current account adjustment occurred. ${ }^{1}$ In brief, we find that a typical current account reversal begins when the current account deficit is about 5 percent of GDP, that it is associated with slowing income growth and a significant real depreciation over a period of about three years. The short-term interest rate displays a hump-shaped pattern, it is elevated by about 2 percent in the year the current account bottomed out. There is some evidence that a large government budget deficit contributes to the current account deficit, but the recovery is not typically associated with a fiscal consolidation. In general, these episodes involve a declining net international investment position that levels off, but does not reverse, a few years after the current account begins its recovery. On the financial side, the recovery is assisted by a sizeable decline in the investment-GDP ratio with little change in the saving-GDP ratio. While declining real import growth aids the initial recovery; a sustained surge in real export growth is the more important force in the continued improvement of the current account over several years.

This exercise has three main motivations. The first is simply to describe the current account adjustment process among industrialized countries. In light of the re-emergence of the

${ }^{1}$ The twenty-five episodes examined are: Australia 1989, Austria 1980, Belgium 1981, Canada 1981 and 1993, Denmark 1986, Finland 1991, France1982, Greece 1985, Hong Kong 1980, Ireland 1981, Israel 1982, Italy 1981 and 1992, Korea 1980, Norway 1986, New Zealand 1984, Portugal 1981, Singapore 1980, Spain 1981 and 1991, Sweden 1982 and 1992, United Kingdom 1989, and United States 1987. We restrict ourselves to episodes in the 1980s and 1990s because only this period involved extensive capital mobility and flexible exchange rates. 
large current account deficit in the United States, it is useful to be able to answer the question of when a typical adjustment begins and what it entails. As noted above, the adjustment process typically begins when the current account deficit is about 5 percent of GDP, it takes 3 to 4 years and involves slowing income growth and a significant real exchange rate depreciation.

The second is to investigate what factors trigger a current account reversal. We find that among industrialized countries, current account reversals are largely a function of the business cycle. The current account worsens when growth is above trend and improves as a recession sets in. Monetary policy plays an important role in smoothing the adjustment. Surprisingly, fiscal policy is roughly orthogonal to the adjustment process.

Third, the results provide empirical evidence that generally favors the conventional wisdom on how the current account adjusts. The standard view maintains that output is demand determined and that a real exchange rate adjustment is necessary to reduce an external deficit. In contrast, others have argued that exchange rate depreciation is not a necessary feature of adjustment. One possibility is that a decline in capital inflows could reduce demand sufficiently so that the exchange rate remains unchanged. This would be true if the foreign and the domestic share of spending on domestic goods was the same at the margin. In such well-integrated economies, only a small relative price adjustment will be needed to accommodate a large shift in capital flows. The most basic version of the intertemporal approach to current account determination also gives no role to the exchange rate. According to this view, the current account is used to smooth consumption, implying that a deficit represents expectations about high future growth relative to other countries. Assuming these expectations are correct, the debt will be repaid when domestic income is relatively high. 
This paper is divided into 6 sections. The next section discusses related empirical literature on current account adjustment. Section 3 examines current account adjustment in the sample countries. Section 4 tests whether exchange rate and real income adjustment during the reversal were different from their period averages. Section 5 discusses alternative theories of adjustment. Section 6 concludes.

\section{Related Literature}

There is a growing empirical literature which focuses on current account determinants and how the current account adjusts. Sachs (1981) evaluates whether oil prices or investment demand was the main determinant of the variation in current account balances across countries in the 1970s. His findings suggest that investment had a greater relative influence on the current account than oil prices. Cashin and McDermott (1998) evaluate the sustainability of Australia's current account deficit and find that it was not used to smooth consumption optimally. Debelle and Faruqee (1996) and Chinn and Prasad (2000) examine the determinants of the current account balance in a cross-section of countries and find some support for stage-of-development theories of current account determination for developing countries.

The paper most closely related to this study is Milesi-Ferretti and Razin (1998), which examines empirical regularities during current account reversals and currency crises using data from 105 low and middle income countries. Their findings on current account reversals are summarized in the following three points:

i. Reversals in current account imbalances are more likely to occur in countries that have run persistent deficits, that have low reserves and unfavorable terms of trade and less likely to occur in countries that receive high official transfers and whose debt is largely on concessional terms. 
ii. Reversals are not systematically associated with a decline in growth-median growth after a reversal is the same as before the reversal. Growth performance after reversals tends to be better in more open economies and in countries whose real exchange rate was less appreciated prior to the reversal.

iii. Currency crises and current account reversals are, in general, distinct events. Less than a third of all current account reversals in their sample were preceded by a currency crisis.

While these stylized facts provide a useful guide to current account adjustment in nonindustrialized countries, they offer little insight into current account reversals in large economies. Indeed, results from Chinn and Prasad (2000) suggest that the determinants of the current account-GDP (CA-GDP) ratio in high-income countries are quite different from those in middleand low-income countries. Among industrialized countries, they find that GDP growth, the net foreign asset-GDP ratio, and the government budget balance all have significant power in explaining the CA-GDP ratio. Among developing countries, they find that while the latter two are also significant determinants of the current account, the magnitude of their impact is much smaller than it was for the industrialized countries. In addition, they find that relative income, financial deepening, and terms-of-trade effects are important determinants of the CA-GDP ratio only in developing countries.

The results from this paper also suggest that there are some similarities and some differences between adjustment processes among industrialized economies and nonindustrialized economies. In particular, one similarity is that adjustments in all economies are associated with a significant real depreciation. However, one important difference is in the relationship between real income growth and current account adjustment. Milesi-Ferretti and Razin do not find a strong relationship between income growth and the current account 
adjustment in non-industrialized countries. ${ }^{2}$ In contrast, we find that declining real income growth is a significant part of the adjustment process among industrialized countries. One possible explanation for this difference is that current account imbalances in developing countries may be driven largely by foreigners willingness to invest and other external factors, while current account imbalances in large economies are more likely to be driven by domestic growth. Another possible explanation is that current account imbalances in many developing nations may be induced by movements in specific commodity prices, which would allow the current account to move independently of real growth. Finally, in industrialized countries, pressure groups may work to limit exchange rate adjustments, forcing real income to do much of the work of external adjustment.

\section{The Dynamics of Current Account Adjustment}

To study the adjustment process we examine twenty-five episodes of current account reversals among industrialized countries. Each episode is identified by the year before the CAGDP began its recovery, i.e. the year the CA-GDP ratio widened to its furthest point in recent years. For example, income in Finland in year 2 refers to income in Finland two years after the CA-GDP ratio reached a local minimum. We examine adjustment in the current account, the exchange rate, real income, the trade balance, savings and investment, the short-term interest rate, the budget balance, and the net international investment position in the ten year period

\footnotetext{
${ }^{2}$ They examine real growth in the three years following the reversal, which might partially explain this finding because adjustment often occurs very rapidly in developing countries. In addition, they note that growth performance is very heterogeneous and that several countries did experience a sharp drop in growth following the reversal.
} 
surrounding the trough date. The data are mainly from the World Bank World Development Indicators (WDI) and the IMF International Financial Statistics. A more detailed description of the data is available in the appendix.

Industrialized countries are defined as those with 1997 per-capita income above $\$ 10,000 .^{3}$ Twenty-five countries fall into this category. ${ }^{4}$ These countries accounted for nearly 80 percent of world trade in the 1990s. We then examine the CA-GDP ratio for each country from 1980 to 1997 . In order for a country to have an episode that qualifies as a reversal, four criteria (similar to those in Milesi-Ferretti and Razin 1998) must be met. They are:

i. The current account deficit exceeded two percent of GDP before the reversal.

ii. The average deficit was reduced by at least two percent of GDP over three years (from the minimum to the three year average).

iii. The maximum deficit in the five years after the reversal was not larger than the minimum deficit in the three years before the reversal.

iv. The current account was reduced by at least one third.

The first restriction ensures that we examine only episodes of adjustment from a current account deficit. The second and third ensure that there was a sustained improvement in the current account. And the final ensures that a small improvement in a very large deficit will not count as an adjustment.

\footnotetext{
${ }^{3}$ The per-capita income level was chosen because there is a natural break in the data around $\$ 10,000$. In addition, the World Bank defines high-income in 1997 to be countries with per-capita GNP above $\$ 9,656$. This definition leads to the addition of one more country in the high-income category, Slovenia, which does not have an episode of current account adjustment. Korea and Portugal are the only countries included in both this study and Milesi-Ferretti and Razin (1998).

${ }^{4}$ Data on per capita GNP was available for 163 countries from the WDI for 1997.
} 
Among these twenty-five countries we identify twenty-five episodes of current account reversal. Table 1 lists the episodes, it reports the year that the CA-GDP ratio was minimized, its value that year, and its value three years later. The magnitude of the deficit-GDP ratio that the country had before adjusting varies from -2.2 percent in France to -16.8 percent in Portugal. After three years, most of the countries show a nearly complete reversal.

Figure 1 plots the median and average CA-GDP ratio for all of the countries. The typical CA-GDP pattern shows a current account that continued to worsen for 4 to 5 years before it hit its minimum and then began adjusting, taking another 3 to 4 years to return to near zero.

\section{The exchange rate}

Figure 2 shows the median and average annual percentage change in the real effective exchange rate index, and Table 2 reports summary statistics on exchange rate depreciation. Both the figure and the summary statistics suggest that the average real depreciation associated with current account adjustment might be small, of about 1 or 2 percent annually. However, these statistics conceal many sharp depreciations that occurred at different times in different countries. The extent of depreciation varies significantly across countries, and in many cases exceeds 10 percent in one year of their adjustment.

Table 3 reports the timing and the extent of depreciation that each country experienced in conjunction with the current account adjustment. In the typical case, the real depreciation began

one year before the current account hit its trough and continued depreciating for three years, with an overall real depreciation of about 20 percent. This implies that there was a significant J-curve effect of the depreciation on the trade deficit; the initial depreciation had little impact on real 
trade and therefore the nominal trade balance worsened. This effect is particularly pronounced in the United States, where the real exchange rate depreciated by 27 percent as the current account continued to worsen (from 1985-1987).

Not surprisingly, the nominal depreciation was in general substantially greater than the real depreciation (Table 3). This suggests that in most countries the adjustment process involved relatively high inflation.

One question this raises is whether currency crisis are more likely to occur around current account reversals or whether they might help to predict current account reversals? To answer this question, we calculate the Frankel and Rose (1996) indicator of currency crises for each country, using monthly data on the local currency -SDR exchange rate from the IMF IFS. Their definition is that a crisis has taken place if the nominal exchange rate depreciated by at least 25 percent over the last year, and by at least 10 percent more than in the previous year. ${ }^{5}$ We further assume that if a country has a crisis in one month it cannot have another crisis over the next six months. This ensures that consecutive months will not be identified as new crises.

Exchange rate regimes and the Frankel and Rose crisis dates are reported in Table 4. From 1980 to 1995 , we identify 21 currency crises, which occurred in 10 of the 25 industrialized countries. All four of the industrialized countries that did not have a current account deficit episode, also did not have currency crises. Of these 21 crises, 17 occurred within two years of a current account episode. However, only 4 crises took place before the current account reversed.

${ }^{5}$ See Edison (2000) for a detailed discussion of various indicators of currency crises, and the advantages and disadvantages of each one. 
This suggests that crises are more likely to occur in countries recovering from large current account deficits, but that they do not help predict current account reversals.

\section{Domestic income growth}

Figure 3 shows the average and median real income growth for the twenty-five episodes, centered around the time the deficit bottomed out. Income growth peaks about two years before the deficit reaches its trough, and is lowest in the first year of recovery. About four-to-five years after the deficit is minimized, income growth returns to its pre-deficit level. This provides evidence that the behavior of the current account is largely cyclical in industrialized countries. Strong income growth leads to a declining current account, and as demand slows the current improves.

In the typical case, annual real income growth was over 3 percent in the years before the current account hit its trough, and then slowed to about 1 percent in the first year that the current account improved (Table 2 and Figure 3). In most countries, income growth was slower in the year after the deficit bottomed out than it had been four years earlier.

In Section 4, we examine whether income growth and exchange rate depreciation are significantly different from their long-run averages during adjustment.

\section{Interest Rates}

Figure 4 shows median and average short-term interest rates, defined as the overnight interbank rate, over the reversal period, and Table 2 reports summary statistics. In most of the countries, short term interest rates were elevated as the current account bottomed out. In the 
typical case, interest rates increased by about 2 percentage points in the final three years the current account deteriorated, and then came down by about 3 percentage points in the first three years the current account reversed.

This hump-shaped short-rate path suggests that interest rates were largely driven by real growth and provides further evidence that much of the behavior of the current account is cyclical. The path is also consistent with monetary authorities attempting to support the exchange rate during its initial decline-before the recovery in the current account began. Recall, that in most episodes the exchange rate depreciation began before the current account bottomed out.

Table 2 also shows the summary statistics for real interest rates (the deposit rate less the rate of inflation). Real interest rates lagged short rates and in the typical case did not come down until the third year into recovery.

\section{Twin Deficits?}

Many of the countries had a general government budget deficit in the year the current account deficit bottomed out. A budget deficit could worsen the international balance because of the impact of higher government spending on aggregate demand. As shown in Figure 5, the deterioration in the current account, however, was not in general associated with an expansion in the budget deficit. This suggests that while the budget deficit in many of these countries may have contributed to the current account deficit, it was not responsible for the deterioration in the

current account. There is some evidence that a few years into recovery some fiscal consolidation took place. 
The bottom of Table 2 provides summary statistics on the budget deficit. In the typical case, there was little change in the budget deficit in the three years leading up to the recovery. However, as growth slowed during the recovery of the current account, most countries experienced growth in the budget deficit-GDP ratio.

\section{The Trade Balance}

For nearly all countries the trade balance was a large contributor to the current account deficit, and with the exception of Canada's 1993 episode, the current account recovery was assisted by a trade balance improvement.

As shown in Figure 6, in the typical case, the trade balance was -2 percent of GDP, when the current account bottomed out. In the previous three years, the trade balance worsened by about 1 to 2 percent of GDP; and in the following three years, the trade balanced improved by about 4 percent of GDP. In the first two years, the recovery was assisted by a decline in the import-GDP ratio as real import growth slowed sharply (see the summary statistics of trade in Table 5). But, the surge in real export growth in the second and third year of recovery was responsible for most of the improvement in the trade balance over the adjustment period (Table 5 and Figures 6-8). Nearly all of the episodes involve an increase in the export-GDP ratio over the first three years of their recovery, while only about half of the countries have a declining importGDP ratio. 


\section{Savings and Investment}

In most countries, the current account decline seems to be associated more with a decline in national savings than with an increase in investment. This supports the view that in most countries the current account deficit was largely demand driven. In contrast, the improvement in the current account comes primarily through reduced investment.

Figures 9 and 10 show the savings-GDP ratio and the investment-GDP ratio and Table 6 shows summary statistics on the change in the saving rate and the investment rate in the three years before and after the current account bottomed out. In the typical case, the saving-GDP ratio fell by about 2 percentage points in the three years preceding the deficit minimum and there was little change in investment. In the next three years of adjustment, the investment-GDP ratio fell by about 4 percent of GDP and there was little change in savings. Nearly all of the countries in the sample had reduced investment in the first two years that the current account improved; only about half of the countries had increased savings.

\section{The Net International Investment Position}

In most of these countries, the net international investment position (NIIP) was declining as the current account worsened. Figure 11 shows the median and average of the NIIP. ${ }^{6}$ Table 6 shows the change in the NIIP in the previous three years and in the following three years. Of fourteen countries for which data is available, ten had a negative NIIP-GDP ratio when the current account deficit hit its trough. In only two of the episodes (Canada 1981 and Italy 1992),

\footnotetext{
${ }^{6}$ Data on the NIIP was not available for the following episodes: Denmark, France, Greece, Hong Kong, Ireland, Israel, Korea, New Zealand, Portugal, Singapore, and Sweden.
} 
was the reversal of the current account associated with a reversal in the NIIP, so that is not a necessary condition for adjustment. ${ }^{7}$ Still, in most of the episodes the reversal was associated with some leveling off of the NIIP a couple of years after the current account bottomed out (Figure 11).

\section{Some Quantifications on Income Growth and the Exchange Rate}

In this section, we examine whether income growth and exchange rate movements are significantly different from their long-run averages. We use data on all industrialized countries, including four that did not experience current account reversals from 1970-1997 in order to more accurately estimate overall macro trends. ${ }^{8}$ We estimate the following simple regression equation:

$$
v_{i t}=\alpha_{i}+\gamma_{t}+\beta_{s}+\varepsilon_{i t}
$$

where $v_{i t}$ is income growth (exchange rate depreciation) in country $i$ at time $t, \alpha_{\mathrm{i}}$ is a countryspecific fixed effect, $\gamma_{\mathrm{t}}$ is a fixed affect for the calendar year, and $\beta_{\mathrm{s}}$ is a fixed effect for the year calibrated relative to the current account trough, and $\epsilon_{\mathrm{it}}$ is an error term which is assumed to be iid. Thus, $\beta_{0}$ is the partial correlation between income growth (exchange rate depreciation) and the year that the current account bottomed out. The $\gamma \mathrm{s}$ are partial correlations between income growth and the calendar years. For example, $\gamma_{1980}$ is the effect of the year 1980 on income growth. The $\gamma s$ will control for worldwide macro variables that might affect income growth (the

\footnotetext{
${ }^{7}$ Mann (1999) examines the financing of large current account deficits in a handful of industrial countries and concludes that there does appear to be a critical value of the NIIP-GDP ratio that triggers a current account reversal (p. 157).

${ }^{8}$ These are Germany, Japan, The Netherlands, and Switzerland.
} 
exchange rate) among industrialized countries in a particular year, such as oil prices or other global shocks.

The regressions were estimated using OLS, with a correction for heteroskedasticity. ${ }^{9}$ For income growth, we test whether each $\beta_{\mathrm{s}}$, from $\beta_{-3}$ through $\beta_{3}$, is significantly different from the average of the time effects $(\beta \mathrm{s})$ over the period. The results are reported in the first column of Table 7. The results show that income growth is below average for four years and is significantly lower than average for two years, by about 1 to 2 percent, during the recovery.

Next, the regression was run with the change in the real exchange rate as the dependant variable. ${ }^{10}$ The results are reported in the second column of Table 7. These results should be interpreted with caution because of the poor fit of this specification. Still, the results suggest that significant depreciation occurs in the first year of recovery and that all of the $\beta$ s are below average around the current account recovery. We also test whether the sum of the $\beta$ s, from three years before the current account bottomed out to the third year of recovery, is significantly different from the seven-year average (column 2). The results are reported in the bottom row of Table 7. They suggest that the current account recovery is associated with a significant real depreciation of about 10 percent over this period. This confirms our earlier results that slowing income growth and a real depreciation are a significant part of the current account reversal.

\footnotetext{
${ }^{9}$ We also include a lag dependent variable to control for possible autocorrelation, and the results were qualitatively unchanged (not reported).

${ }^{10}$ In this specification, we exclude the four countries that did not have current account reversals.
} 


\section{Alternative Theories of Adjustment}

While current account adjustment typically involves a real depreciation and a slowdown in GDP growth, there is some idiosyncratic noise that sometimes exaggerates and sometimes mutes the typical story. In particular, a few exceptions to the typical case exist, proving that in some cases adjustment can occur without an exchange rate depreciation and/or a slowdown in GDP growth. Specifically, the current account reversals in Canada, Denmark, and Norway were accomplished without a real or a nominal depreciation, and in Singapore the reversal took place with neither a depreciation nor a slowdown in GDP growth. Each of these is to some extent a special case, but it is still interesting to examine how adjustment occurred.

In Canada, the effective exchange rate indices are somewhat misleading because they conceal a large depreciation of the Canadian dollar with respect to the U.S. dollar. From 1976 to 1986 the Canadian dollar depreciated by 34 percent against the U.S. dollar, about half of which took place as the current account improved. Since the Canadian adjustment took place primarily vis-a-vis the United States, Canada's episode remains broadly consistent with traditional theory.

In Norway, the current account deficit was the result of an oil price shock. The price of oil fell by nearly 50 percent in 1986 from its level in the previous year. The sharp decline in the oil price reduced the value of Norwegian exports and the current account moved from a surplus of about 5 percent to a deficit of 5 percent in one year. As oil prices rebounded over the next few years, the current account recovered.

The Danish and Singaporean experiences are more interesting. As a member of the European Monetary System, Denmark was required to keep the spot exchange rates between the Krone and the currencies of the other participants within margins of 2.25 percent. The Krone 
was under pressure to fall below its exchange band in 1987, but the central bank used the overnight interest rate to defend the currency. The Danish Central Bank reports that "when the foreign exchange crisis peaked in January 1987 the short-term interest rate was raised from 9.25 percent to 14 percent per annum" (Jespersen 1987). The decline in capital inflows in conjunction with the monetary tightening reduced domestic demand sufficiently that the current account improved while the exchange rate remained unchanged. Walter (1991) notes a similar pattern of current account adjustment in Germany (Denmark's largest trade partner). Germany's current account has fluctuated widely with respect to its western European neighbors, while Germany maintained a fixed exchange rate. This suggests that some European countries may be sufficiently well-integrated that they can adjust with only small changes in short rates, while exchange rates remain fixed.

Singapore is perhaps the most interesting exception, experiencing neither an exchange rate depreciation nor a slowdown in GDP growth as the current account improved. Adjustment in Singapore is qualitatively consistent with the intertemporal story; the current account was in deficit because Singapore's net income was expected to grow relative to other countries, which is in fact what happened. Singapore was an international borrower in the late 1970's and imported primarily capital goods, the investment paid off, and in the period following the reversal Singapore experienced the strongest growth of all the countries in the sample.

\section{Conclusion}

This paper has attempted to provide a brief characterization of the process of current account adjustment in industrialized countries. A typical adjustment occurs after the current 
account deficit has grown for about four years and reaches about 5 percent of GDP. The results from previous episodes suggest that reversals involve a real depreciation of 10 to 20 percent and slow real income growth for a period of about three years. Real export growth, declining investment, and an eventual leveling off in the net international investment position and in the budget deficit-GDP ratio are also likely to be part of the adjustment. 


\section{References}

Cashin P. and C.J. McDermott (1998), "Are Australia's Current Account Deficits Excessive?" Economic Record, December 1, 1998, v. 74, iss. 227, pp. 346-61

Chinn, M and E. Prasad (2000), "Medium-Term Determinants of Current Accounts in Industrial and Developing Countries: An Empirical Exploration." NBER Working Paper \#7581.

Debelle, G. and H. Faruqee (1996), "What Determines the Current Account? A Cross-Sectional and Panel Approach" International Monetary Fund Working Paper: WP/96/58.

Edison, H. (2000), "Do Indicators of Financial Crises Really Work: An Evaluation of an Early Warning System" International Finance Discussion Paper \#675, Federal Reserve Board, Washington D.C.

Frankel, J. and A. Rose (1996), "Currency Crashes in Emerging Markets: An Empirical Treatment" Journal of International Economics 41, November, 351-66.

International Monetary Fund, Annual Report on Exchange Arrangements and Exchange Restrictions, Various issues 1980-1997.

Jespersen, J. (1988), "Monetary Policy in 1987" in Danmarks Nationalbank Monetary Review May, p. 6-9.

Mann, C. (1999), Is the U.S. Trade Deficit Sustainable? Institute for International Economics: Washington D.C.

Milesi-Ferretti, G. M. and A. Razin (1998), "Current Account Reversals and Currency Crises: Empirical Regularities" NBER working paper \#6620.

Sachs, J. (1981), "The Current Account and Macroeconomic Adjustment in the 1970s" Brookings Papers on Economic Activity.

Walter, N. (1991), "German External Adjustment Since 1985" In Fred Bergsten Ed., International Adjustment and Financing: the Lessons of 1985-1991, Institute for International Economics: Washington D.C., pp. 155-177. 


\section{Data Appendix}

The current account balance relative to GDP, real GDP in local currency units, the government budget balance as a share of GDP, gross domestic savings and gross domestic investment as a share of GDP, exports and imports as a share of GDP, real exports, real imports, and the real interest rate are from the World Bank, World Development Indicators.

The real effective exchange rate is the nominal effective exchange rate adjusted for changes in consumer prices and is from the IMF, International Financial Statistics (IFS). The money market rate and the nominal market SDR exchange rate are also from the IMF, IFS.

The net international investment position and the capital flow data are from the IMF, Balance of Payments Statistics. 
Table 1: 25 Episodes of Current Account Adjustment

\begin{tabular}{|c|c|c|c|}
\hline \multirow[t]{2}{*}{ Country (year) } & \multicolumn{2}{|c|}{ CA-GDP Ratio } & \multirow{2}{*}{$\begin{array}{l}\text { Percent change over } \\
\text { three years }\end{array}$} \\
\hline & Year $=0$ & Year $=3$ & \\
\hline Australia (1989) & -6.20 & -3.74 & 40 \\
\hline Austria (1980) & -4.92 & 0.40 & 108 \\
\hline Belgium (1981) & -4.23 & -0.07 & 98 \\
\hline Canada (1981) & -4.21 & -0.40 & 91 \\
\hline Canada (1993) & -3.94 & 0.56 & 114 \\
\hline Denmark (1986) & -5.33 & -1.04 & 81 \\
\hline Finland (1991) & -5.52 & 1.30 & 124 \\
\hline France (1982) & -2.18 & -0.01 & 100 \\
\hline Greece (1985) & -8.09 & -1.48 & 82 \\
\hline Hong Kong (1980) & -5.03 & 0.57 & 111 \\
\hline Ireland (1981) & -13.63 & -5.59 & 59 \\
\hline Israel (1982) & -8.66 & 4.79 & 155 \\
\hline Italy (1981) & -2.58 & -0.78 & 70 \\
\hline Italy (1992) & -2.47 & 2.31 & 194 \\
\hline Korea (1980) & -8.46 & -1.84 & 78 \\
\hline New Zealand (1984) & -13.59 & -8.00 & 41 \\
\hline Norway (1986) & -6.02 & 0.21 & 104 \\
\hline Portugal (1981) & -16.78 & -2.83 & 83 \\
\hline Singapore (1980) & -13.34 & -3.51 & 74 \\
\hline Spain (1981) & -2.88 & 1.11 & 139 \\
\hline Spain (1981) & -3.75 & -1.43 & 62 \\
\hline Sweden (1980) & -3.45 & -0.78 & 77 \\
\hline Sweden (1992) & -3.56 & 2.14 & 160 \\
\hline United Kingdom (1989) & -4.36 & -1.75 & 60 \\
\hline United States (1987) & -3.72 & -1.65 & 56 \\
\hline Median & -4.92 & -0.78 & 83 \\
\hline Mean & -6.28 & -0.86 & 94 \\
\hline
\end{tabular}


Table 2: Summary Statistics, Macro Fundamentals

\begin{tabular}{|c|c|c|c|c|c|c|}
\hline \multirow[b]{2}{*}{$\begin{array}{l}\text { Real Exchange Rate } \\
\text { Ap(+)/Depreciation(-) }\end{array}$} & \multicolumn{6}{|c|}{ Year Relative to Deficit Minimum } \\
\hline & -2 & -1 & $\mathbf{0}$ & 1 & 2 & 3 \\
\hline Median (percent) & 2.07 & -1.45 & -0.97 & -0.41 & -1.15 & -0.42 \\
\hline Mean (percent) & -1.37 & -2.48 & -1.08 & -2.33 & -2.15 & -0.74 \\
\hline No. appreciating ${ }^{\mathrm{a}}$ & 13 & 10 & 10 & 9 & 10 & 9 \\
\hline No. depreciating ${ }^{\mathrm{a}}$ & 8 & 12 & 13 & 14 & 13 & 13 \\
\hline \multicolumn{7}{|l|}{ Real GDP Growth } \\
\hline Median (percent) & 4.00 & 3.92 & 2.29 & 0.78 & 1.16 & 2.54 \\
\hline Mean (percent) & 3.84 & 4.00 & 2.13 & 1.62 & 1.37 & 2.90 \\
\hline No. increasing & 24 & 24 & 20 & 19 & 17 & 23 \\
\hline No. decreasing & 1 & 1 & 5 & 6 & 8 & 2 \\
\hline \multicolumn{7}{|c|}{ Change in Short Rates from previous year } \\
\hline Median (percentage points) & 0.37 & 0.25 & 1.12 & 0.53 & -1.68 & -1.66 \\
\hline Mean (percentage points) & -0.01 & 0.59 & 1.18 & -0.21 & -1.27 & -1.58 \\
\hline No. increasing ${ }^{\mathrm{a}}$ & 12 & 11 & 13 & 14 & 5 & 6 \\
\hline No. decreasing ${ }^{\mathrm{a}}$ & 9 & 10 & 9 & 8 & 17 & 16 \\
\hline \multicolumn{7}{|c|}{ Change in Real Interest Rates from previous year } \\
\hline Median (percentage points) & 0.48 & -0.07 & -0.70 & 0.57 & 0.84 & -0.63 \\
\hline Mean (percentage points) & 0.92 & 0.52 & 0.80 & 0.59 & 3.96 & -1.15 \\
\hline No. increasing ${ }^{\mathrm{a}}$ & 11 & 10 & 10 & 15 & 14 & 7 \\
\hline No. decreasing ${ }^{\mathrm{a}}$ & 9 & 11 & 11 & 7 & 8 & 15 \\
\hline \multicolumn{7}{|c|}{ Change in Budget Balance from previous year } \\
\hline Median (percentage points) & -0.12 & -0.57 & -0.37 & -0.30 & 0.10 & -0.59 \\
\hline Mean (percentage points) & 0.53 & -0.86 & -0.40 & -1.22 & 0.41 & 0.57 \\
\hline No. increasing ${ }^{\mathrm{a}}$ & 11 & 10 & 7 & 10 & 12 & 7 \\
\hline No. decreasing ${ }^{\mathrm{a}}$ & 13 & 14 & 17 & 14 & 12 & 16 \\
\hline
\end{tabular}

a. The total number of observations varies by year because of missing data. 
Table 3: The Exchange Rate

\begin{tabular}{|c|c|c|c|c|c|c|c|c|}
\hline & \multicolumn{4}{|l|}{ Real } & \multicolumn{4}{|l|}{ Nominal } \\
\hline & Depreciation & Began $^{a}$ & Ended $^{\mathrm{b}}$ & Duration & Depreciation & Began $^{a}$ & Ended $^{\mathrm{b}}$ & Duration \\
\hline Australia89 & 21 & 1 & 5 & 4 & 25 & 0 & 5 & 5 \\
\hline Austria80 & 19 & -1 & 2 & 3 & 28 & 0 & 5 & 5 \\
\hline Belgium81 & 51 & -3 & 4 & 7 & 51 & -1 & 4 & 5 \\
\hline Canada81 & -- & -- & -- & -- & -- & -- & -- & -- \\
\hline Canada93 & 19 & -1 & 3 & 4 & 30 & -3 & 2 & 5 \\
\hline Denmark86 & -- & -- & -- & -- & -- & -- & -- & -- \\
\hline Finland91 & 30 & -1 & 2 & 3 & 43 & 0 & 3 & 3 \\
\hline France82 & 15 & -1 & 3 & 4 & 57 & -2 & 3 & 5 \\
\hline Greece85 & 21 & -2 & 2 & 4 & $94^{\mathrm{c}}$ & -2 & 4 & 6 \\
\hline Hong Kong80 & n.a. & n.a. & n.a. & n.a. & 41 & -3 & 4 & 7 \\
\hline Ireland81 & 41 & -2 & 1 & 3 & 48 & -3 & 4 & 7 \\
\hline Israel82 & 14 & 2 & 6 & 4 & $700^{c}$ & -3 & 6 & 9 \\
\hline Italy81 & 12 & -1 & 1 & 2 & 58 & -1 & 4 & 5 \\
\hline Italy92 & 28 & 0 & 4 & 4 & 39 & -1 & 3 & 4 \\
\hline Korea80 & n.a. & n.a. & n.a. & n.a. & 40 & -3 & 1 & 4 \\
\hline New Zealand84 & 11 & -1 & 1 & 2 & 57 & -3 & 3 & 6 \\
\hline Norway86 & 5 & -3 & 1 & 4 & 8 & 0 & 1 & 1 \\
\hline Portugal81 & 8 & 1 & 3 & 2 & $90^{c}$ & 0 & 4 & 4 \\
\hline Singapore80 & n.a. & n.a. & n.a. & n.a. & -- & -- & -- & -- \\
\hline Spain81 & 36 & -1 & 3 & 4 & 67 & -1 & 4 & 5 \\
\hline Spain91 & 17 & 1 & 4 & 3 & 35 & 0 & 3 & 3 \\
\hline Sweden 80 & 20 & 1 & 4 & 3 & 48 & 0 & 5 & 5 \\
\hline Sweden92 & 21 & 1 & 4 & 3 & 37 & 0 & 2 & 2 \\
\hline $\begin{array}{l}\text { United } \\
\text { Kingdom89 }\end{array}$ & 15 & 3 & 5 & 2 & 10 & 0 & 1 & 1 \\
\hline United States87 & 34 & -1 & 2 & 3 & 37 & -2 & 1 & 3 \\
\hline Median & 19 & -1 & 3 & 3 & 42 & -1 & 3.5 & 5 \\
\hline
\end{tabular}

Notes: n.a. not available. -- no exchange rate depreciation around the time of the deficit. a. The first year that the exchange rate depreciated relative to the previous year. $b$. The first year the exchange appreciated relative to the previous year, following the period of depreciation. c. The currency was depreciating throughout the period, but by relatively more in these years. 
Table 4: Currency Crises

\begin{tabular}{|c|c|c|c|}
\hline & CA/GDP (year) & Exchange Regime $^{\mathrm{a}}$ & Currency Crises Dates \\
\hline Australia & $-6.20(1989)$ & Independent floating & $\begin{array}{l}\text { April } 1985 \\
\text { November } 1985 \\
\text { July } 1986\end{array}$ \\
\hline Austria & $-4.92(1980)$ & Cooperative arrangement & No \\
\hline Belgium & $-4.23(1981)$ & Cooperative arrangement & No \\
\hline Canada & $\begin{array}{l}-4.21(1981) \\
-3.94(1993)\end{array}$ & Independent floating & No \\
\hline Denmark & $-5.33(1986)$ & Cooperative arrangement & No \\
\hline Finland & $-5.52(1991)$ & Cooperative arrangement & February 1993 \\
\hline France & $-2.18(1982)$ & Cooperative arrangement & No \\
\hline Greece & $-8.09(1985)$ & Managed floating & $\begin{array}{l}\text { January } 1983 \\
\text { November } 1983\end{array}$ \\
\hline Hong Kong & $-5.03(1980)$ & Pegged & No \\
\hline Ireland & $-13.63(1981)$ & Cooperative arrangement & No \\
\hline Israel & $-8.66(1982)$ & Managed floating & $\begin{array}{l}\text { June } 1980 \\
\text { March } 1981 \\
\text { October } 1983 \\
\text { May } 1984 \\
\text { December } 1984\end{array}$ \\
\hline Italy & $\begin{array}{l}-2.58(1981) \\
-2.47(1992)\end{array}$ & Cooperative arrangement & February 1993 \\
\hline Korea & $-8.46(1980)$ & Managed floating & August 1980 \\
\hline New Zealand & $-13.59(1984)$ & $\begin{array}{l}\text { Independent floating (as of 12/84) } \\
\text { Managed floating }\end{array}$ & January 1985 \\
\hline Norway & $-6.02(1986)$ & Managed floating & None \\
\hline Portugal & $-16.78(1981)$ & Cooperative arrangement & $\begin{array}{l}\text { October } 1982 \\
\text { May } 1983 \\
\text { July } 1993\end{array}$ \\
\hline Singapore & $-13.34(1980)$ & Managed floating & None \\
\hline Spain & $\begin{array}{l}-2.88(1981) \\
-3.75(1991)\end{array}$ & Cooperative arrangement & $\begin{array}{l}\text { July } 1983 \\
\text { May } 1993\end{array}$ \\
\hline Sweden & $\begin{array}{l}-3.45(1980) \\
-3.56(1992)\end{array}$ & $\begin{array}{l}\text { Independent floating (as of 11/92) } \\
\text { Managed floating }\end{array}$ & $\begin{array}{l}\text { February } 1993 \\
\text { September } 1993\end{array}$ \\
\hline United Kingdom & $-4.36(1989)$ & $\begin{array}{l}\text { Independent floating (as of 9/92) } \\
\text { Cooperative agreement }\end{array}$ & None \\
\hline United States & $-3.72(1987)$ & Independent floating & None \\
\hline Germany & None & Cooperative arrangement & None \\
\hline Japan & None & Independent floating & None \\
\hline Netherlands & None & Cooperative arrangement & None \\
\hline Switzerland & None & Independent floating & None \\
\hline
\end{tabular}

a. IMF Annual Report on Exchange Arrangements and Exchange Restrictions, various issues. Currency crises are defined using a modified Frankel and Rose (1996) index. 
Table 5: Summary Statistics, Trade

\begin{tabular}{|c|c|c|c|c|c|c|}
\hline \multirow[b]{2}{*}{$\begin{array}{l}\text { Change in Trade Balance- } \\
\text { GDP from previous year }\end{array}$} & \multicolumn{6}{|c|}{ Year Relative to Deficit Minimum } \\
\hline & -2 & -1 & $\mathbf{0}$ & 1 & 2 & 3 \\
\hline Median (percentage points) & -0.46 & -0.45 & -0.74 & 1.51 & 1.67 & 0.89 \\
\hline Mean (percentage points) & -0.40 & -0.70 & -1.17 & 1.66 & 1.82 & 1.21 \\
\hline No. increasing & 8 & 10 & 7 & 24 & 23 & 21 \\
\hline No. decreasing & 19 & 15 & 18 & 1 & 2 & 4 \\
\hline \multicolumn{7}{|c|}{ Change Import-GDP ratio from previous year } \\
\hline Median (percentage points) & 0.57 & 0.79 & 0.72 & -0.79 & -0.13 & 0.99 \\
\hline Mean (percentage points) & 0.98 & 1.63 & 1.91 & -0.88 & -1.08 & 0.51 \\
\hline No. increasing & 17 & 17 & 19 & 10 & 12 & 18 \\
\hline No. decreasing & 8 & 8 & 6 & 15 & 13 & 7 \\
\hline \multicolumn{7}{|c|}{ Change Export-GDP ratio from previous year } \\
\hline Median (percentage points) & 0.28 & -0.03 & 0.07 & 0.61 & 1.47 & 2.24 \\
\hline Mean (percentage points) & 0.58 & 0.93 & 0.74 & 0.77 & 0.74 & 1.71 \\
\hline No. increasing & 14 & 12 & 13 & 17 & 17 & 20 \\
\hline No. decreasing & 11 & 13 & 12 & 8 & 8 & 5 \\
\hline \multicolumn{7}{|l|}{ Real Import growth } \\
\hline Median (percent) & 7.85 & 6.43 & 5.15 & 1.09 & 2.01 & 6.38 \\
\hline Mean (percent) & 7.61 & 6.36 & 4.78 & 0.49 & 2.08 & 6.64 \\
\hline No. increasing & 23 & 20 & 20 & 15 & 16 & 22 \\
\hline No. decreasing & 2 & 5 & 5 & 10 & 9 & 3 \\
\hline \multicolumn{7}{|l|}{ Real Export growth } \\
\hline Median (percent) & 6.27 & 3.61 & 4.58 & 4.95 & 7.49 & 8.58 \\
\hline Mean (percent) & 6.74 & 4.89 & 4.42 & 6.44 & 7.44 & 9.32 \\
\hline No. increasing & 25 & 23 & 20 & 23 & 23 & 25 \\
\hline No. decreasing & 0 & 2 & 5 & 2 & 2 & 0 \\
\hline
\end{tabular}


Table 6: Summary Statistics, Financial Flows

\begin{tabular}{|c|c|c|c|c|c|c|}
\hline Change from previous & \multicolumn{6}{|c|}{ Year Relative to Deficit Minimum } \\
\hline Savings/GDP & -2 & -1 & $\mathbf{0}$ & 1 & 2 & 3 \\
\hline Median (percentage points) & 0.47 & -0.46 & -0.61 & -0.30 & 0.34 & 0.91 \\
\hline Mean (percentage points) & 0.13 & -0.43 & -1.01 & -0.04 & 0.15 & 0.61 \\
\hline No. increasing & 13 & 8 & 9 & 11 & 15 & 16 \\
\hline No. decreasing & 12 & 17 & 16 & 14 & 10 & 9 \\
\hline \multicolumn{7}{|l|}{ Investment /GDP } \\
\hline Median (percentage points) & 0.61 & 0.26 & 0.53 & -1.77 & -1.56 & -0.10 \\
\hline Mean (percentage points) & 0.53 & 0.27 & 0.16 & -1.70 & -1.66 & -0.59 \\
\hline No. increasing & 15 & 14 & 14 & 3 & 5 & 11 \\
\hline No. decreasing & 10 & 11 & 11 & 22 & 20 & 14 \\
\hline \multicolumn{7}{|l|}{ NIIP/GDP } \\
\hline Median (percentage points) & -2.07 & -0.42 & -2.49 & -3.19 & -0.24 & 1.54 \\
\hline Mean (percentage points) & -3.89 & -1.10 & -1.05 & -3.80 & -0.27 & 1.16 \\
\hline No. increasing ${ }^{\mathrm{a}}$ & 2 & 3 & 2 & 4 & 7 & 9 \\
\hline No. decreasing $^{\mathrm{a}}$ & 10 & 9 & 10 & 10 & 8 & 6 \\
\hline
\end{tabular}

a. The total number of observations varies by year because of missing data. 
Table 7: Panel Estimation for Income Growth and Exchange Rate Depreciation

\begin{tabular}{|c|c|c|}
\hline \multicolumn{3}{|c|}{ Test of the hypothesis that $\beta_{\mathrm{s}}=\operatorname{Mean}\left(\beta_{\mathrm{s}}\right)$} \\
\hline & $\begin{array}{l}\text { Income Growth } \\
\text { (1) }\end{array}$ & $\begin{array}{l}\text { Exchange Rate Depreciation } \\
\text { (2) }\end{array}$ \\
\hline$s=-3$ & $\begin{array}{l}0.71 \\
(1.70)\end{array}$ & $\begin{array}{l}-0.78 \\
(-0.57)\end{array}$ \\
\hline$s=-2$ & $\begin{array}{l}0.32 \\
(0.81)\end{array}$ & $\begin{array}{l}-0.56 \\
(-0.25)\end{array}$ \\
\hline$s=-1$ & $\begin{array}{l}0.69^{*} \\
(2.02)\end{array}$ & $\begin{array}{l}-1.49 \\
(-0.86)\end{array}$ \\
\hline $\mathrm{s}=0$ & $\begin{array}{l}-0.54 \\
(-0.94)\end{array}$ & $\begin{array}{l}-0.95 \\
(-0.75)\end{array}$ \\
\hline $\mathrm{s}=1$ & $\begin{array}{l}-1.15^{*} \\
(-2.95) \\
\end{array}$ & $\begin{array}{l}-3.28^{*} \\
(-2.29)\end{array}$ \\
\hline $\mathrm{s}=2$ & $\begin{array}{l}-1.58^{*} \\
(-4.04)\end{array}$ & $\begin{array}{l}-1.93 \\
(-1.50)\end{array}$ \\
\hline $\mathrm{s}=3$ & $\begin{array}{l}-0.56 \\
(-1.38)\end{array}$ & $\begin{array}{l}-0.68 \\
(-0.55)\end{array}$ \\
\hline $\begin{array}{l}\text { Test of hypothesis that the sum of } \beta_{-3} \\
\text { through } \beta_{3} \text { is equal to the sum of means. }\end{array}$ & & $\begin{array}{l}-9.67 * \\
(-2.81)\end{array}$ \\
\hline No. of Observations & 575 & 425 \\
\hline R-Squared & 0.59 & 0.13 \\
\hline
\end{tabular}

Note: All regressions include country fixed effects, calendar-year fixed effects, and year-relative-to-currentaccount-trough fixed effects. The regressions were run with a correction for heteroskedasticity (White 1980). Tstatistics in parentheses. * Significant at the five percent level. 
Figure 1: Current Account/GDP

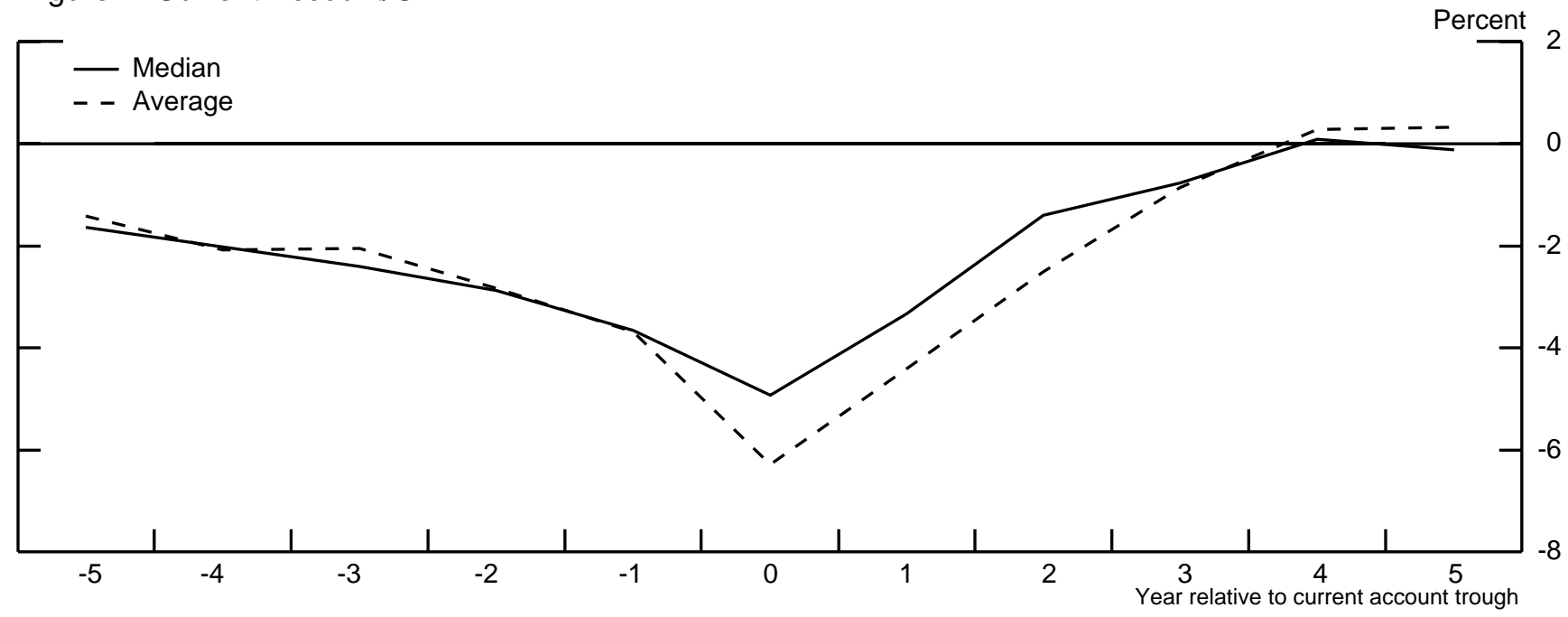

Figure 2: Real Depreciation

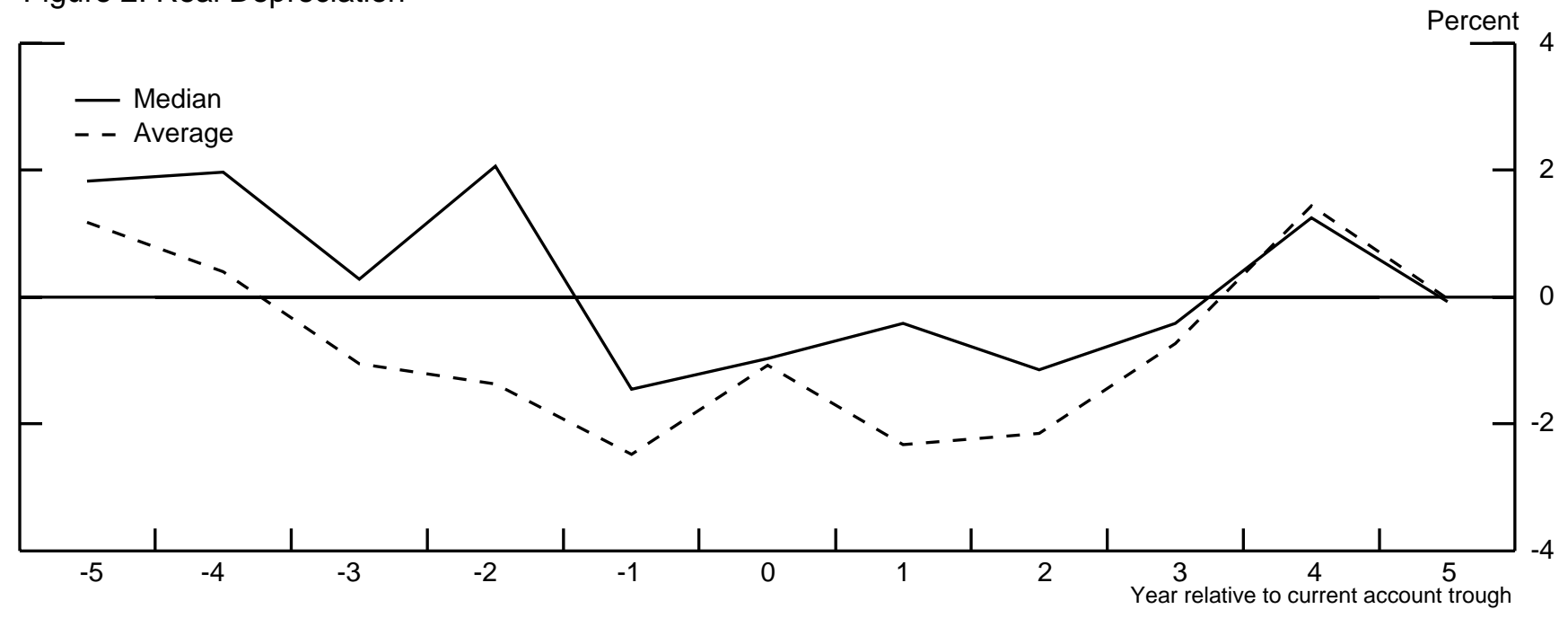

Figure 3: Real GDP Growth

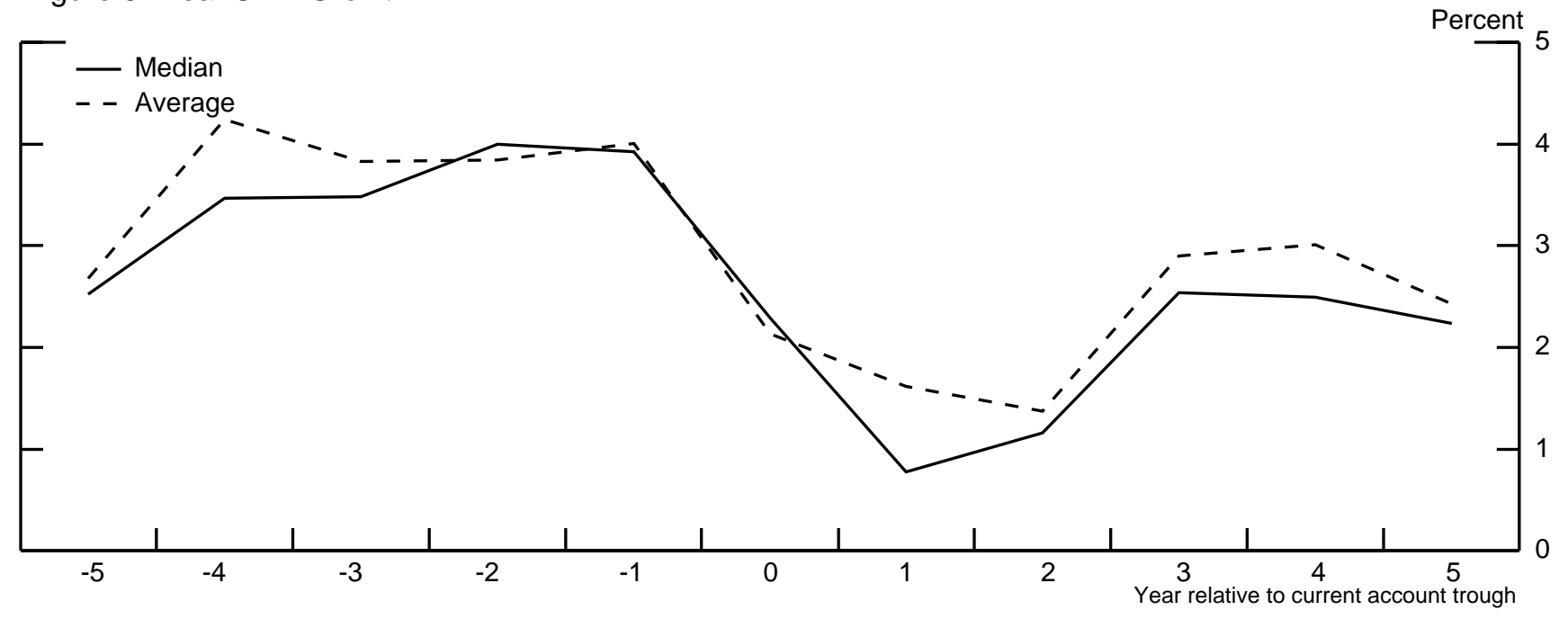


Figure 4: Money Market Rates

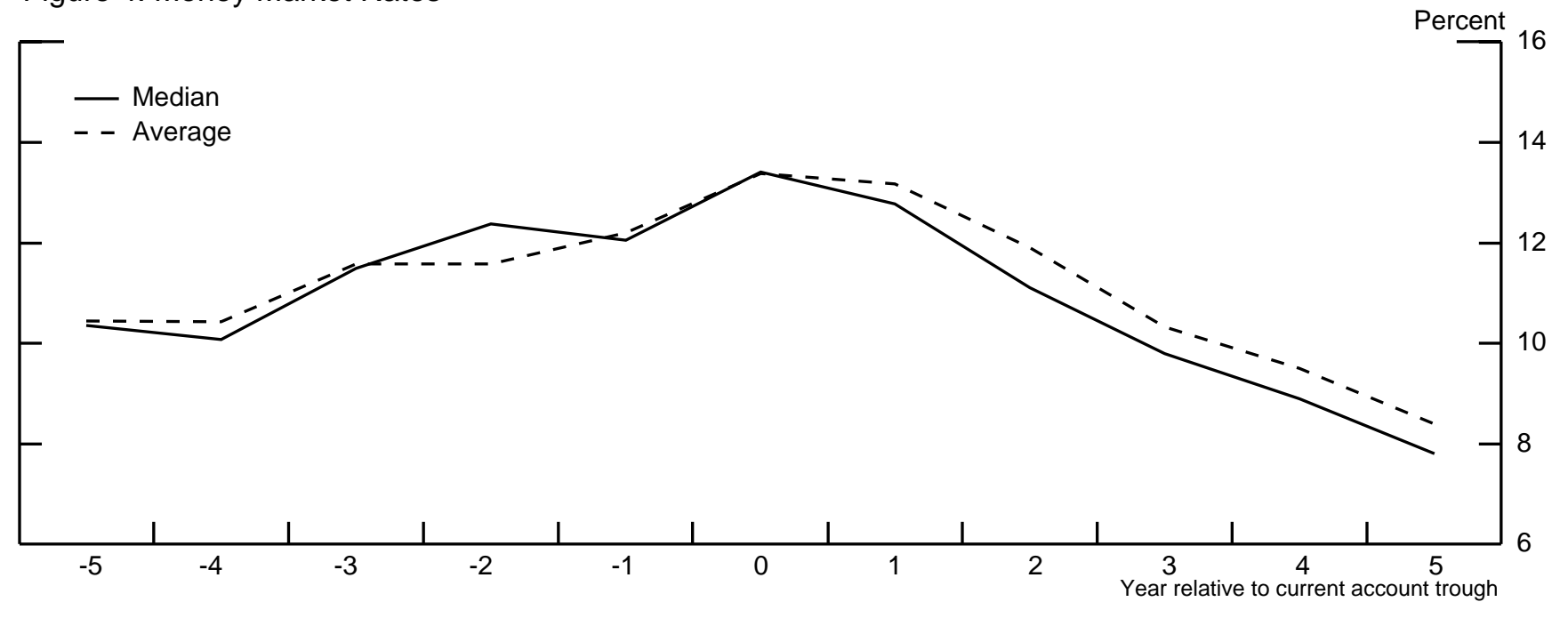

Figure 5: Budget Balance / GDP

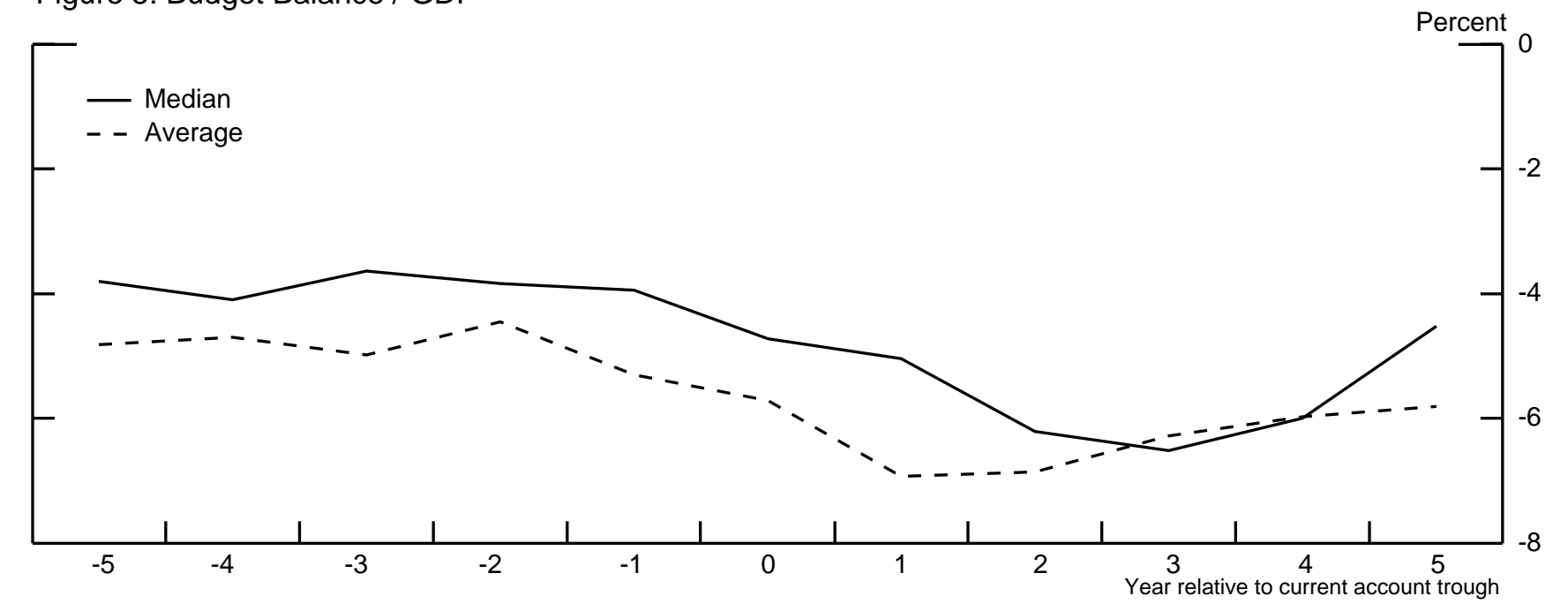


Figure 6: Net Exports / GDP

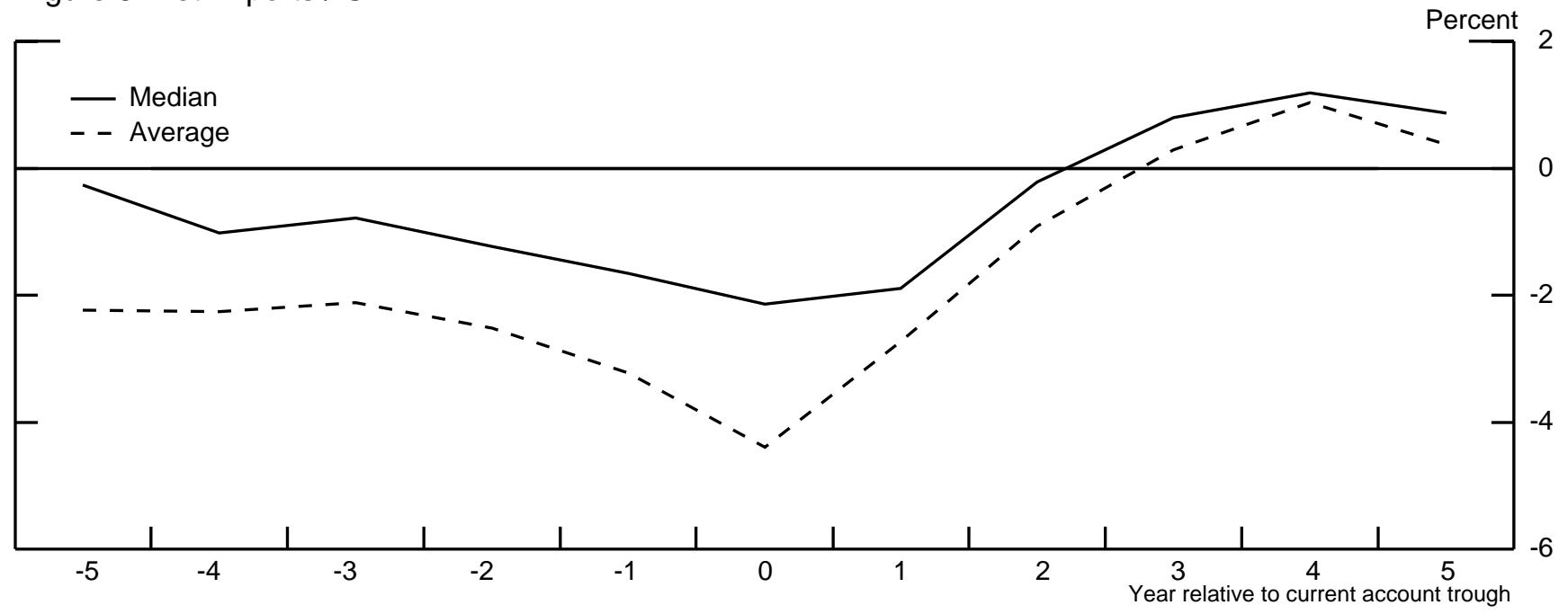

Figure 7: Imports / GDP

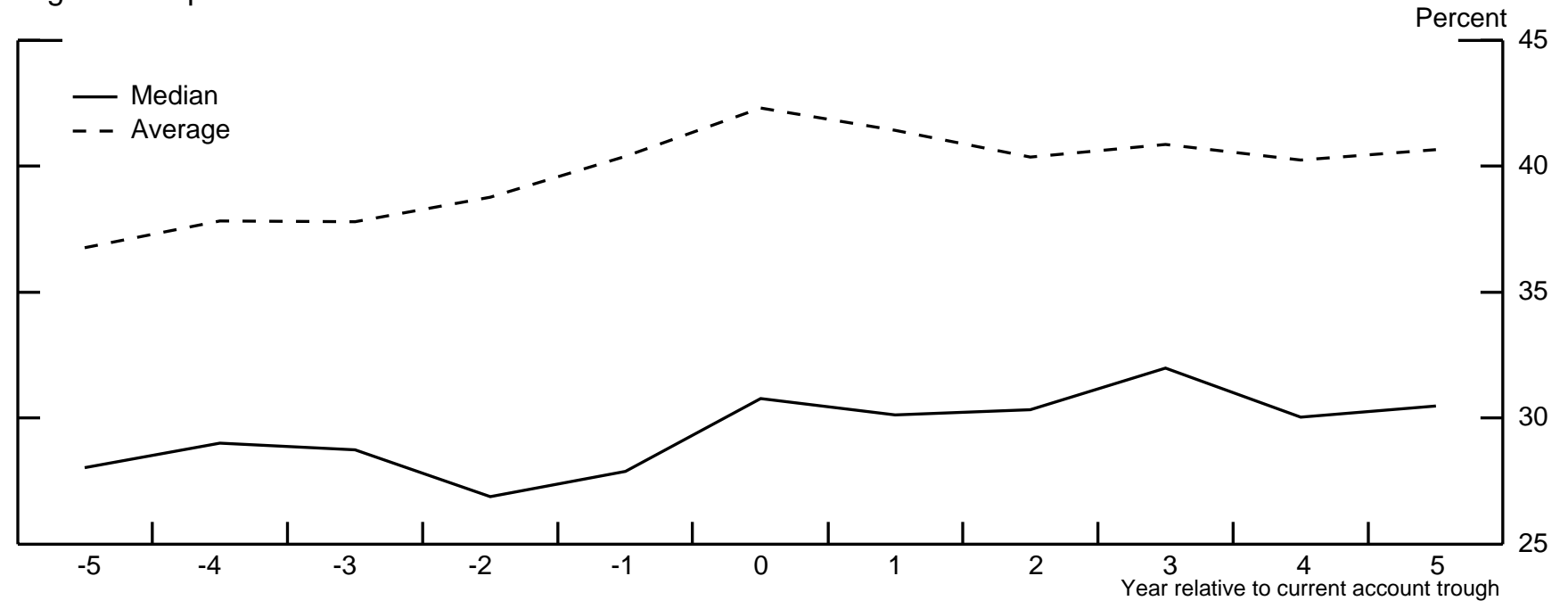

Figure 8: Exports / GDP

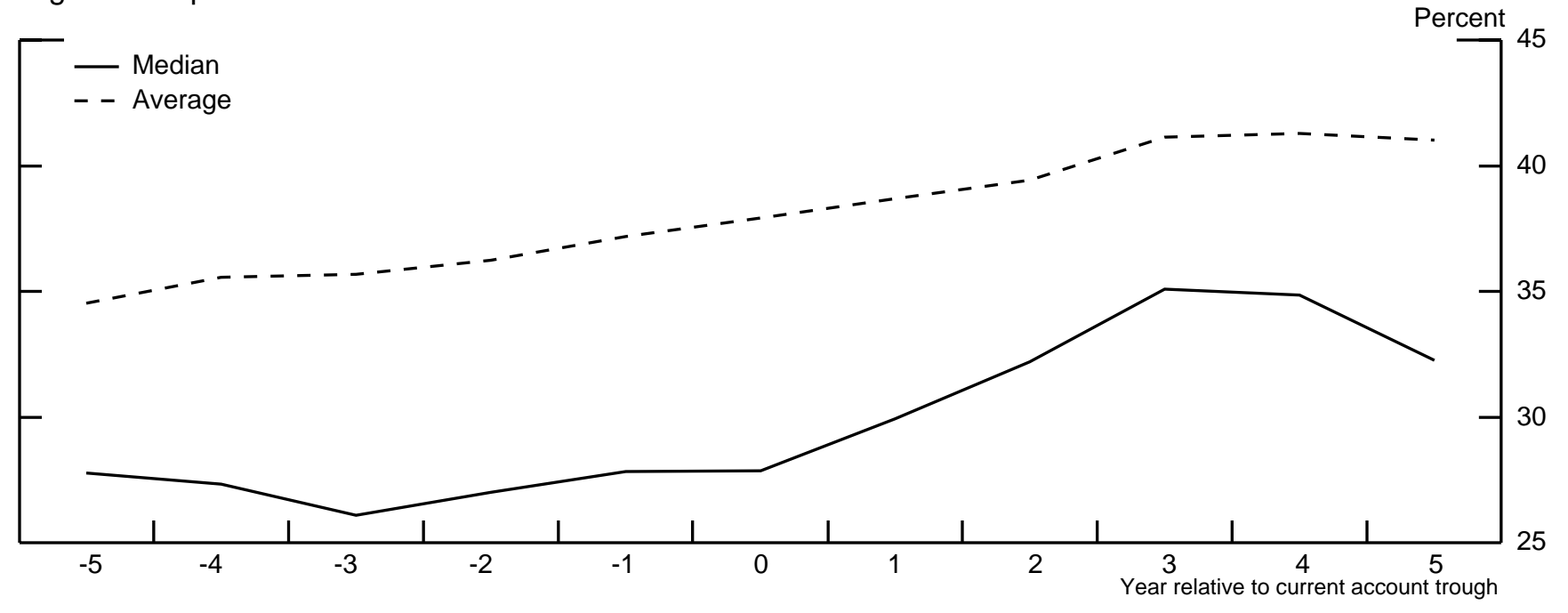


Figure 9: Saving / GDP

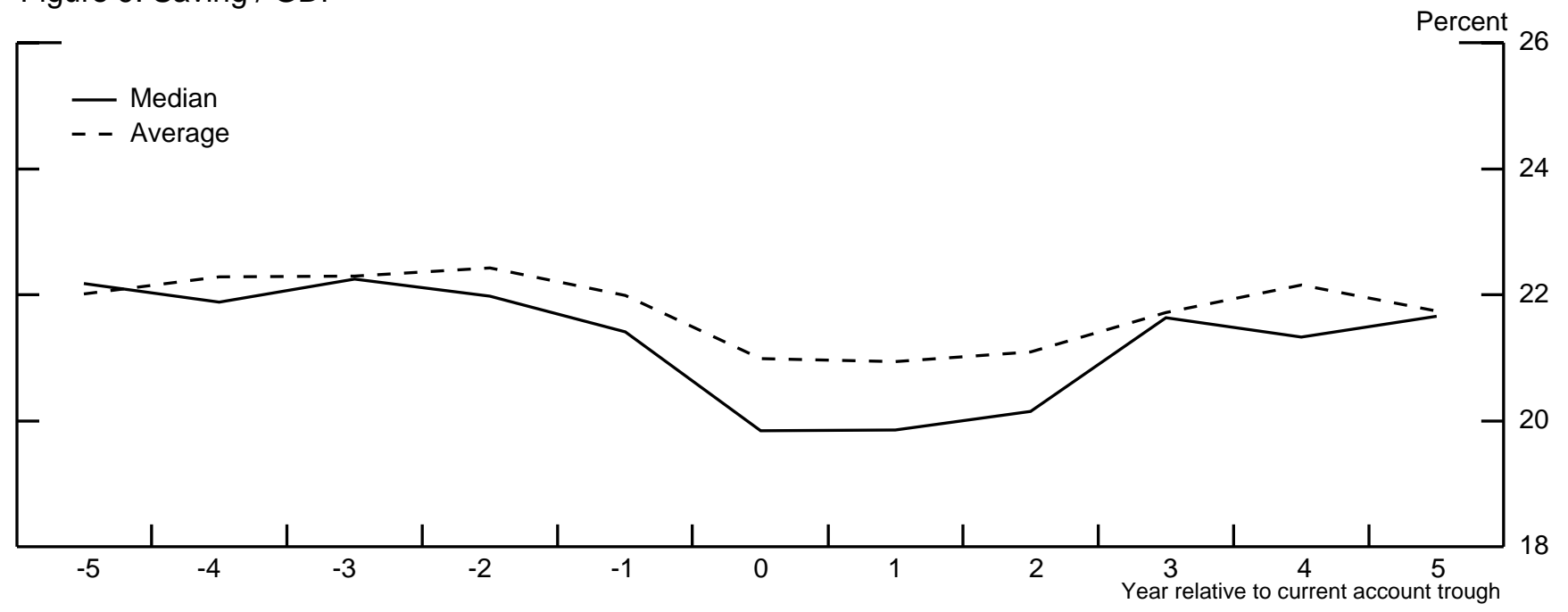

Figure 10: Investment / GDP

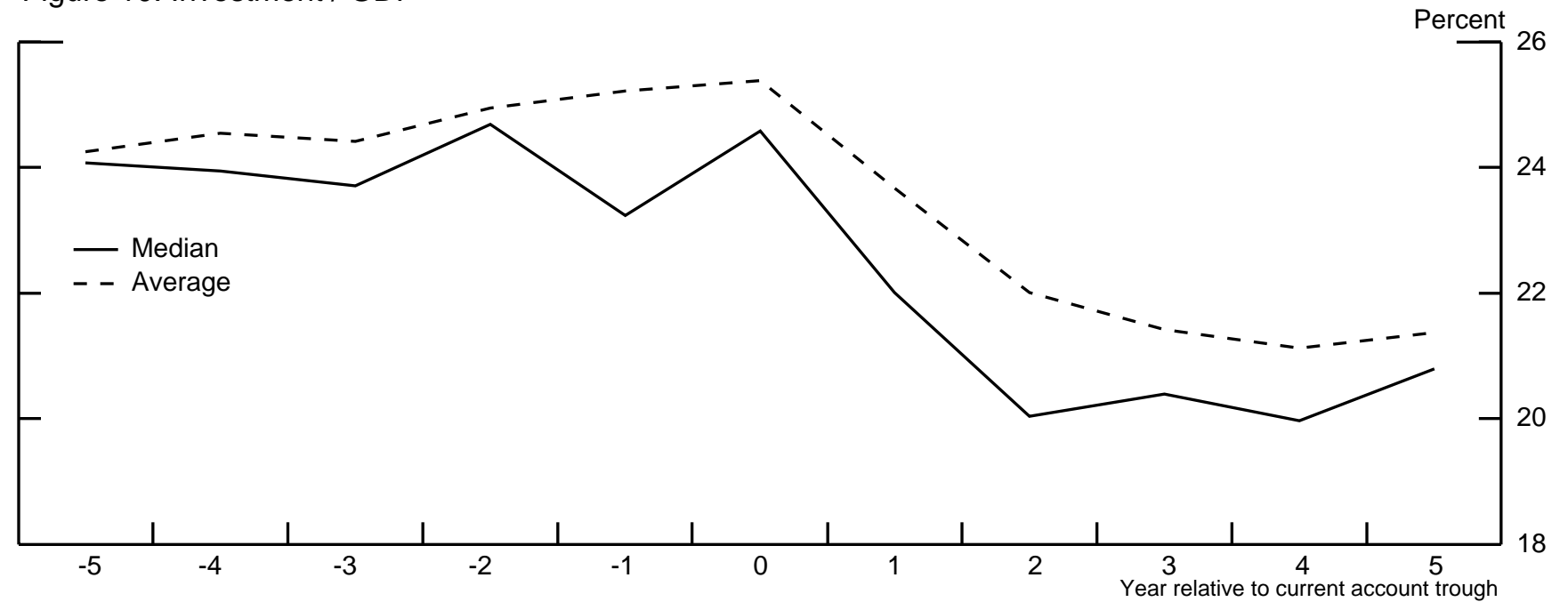

Figure 11: Net International Investment Position

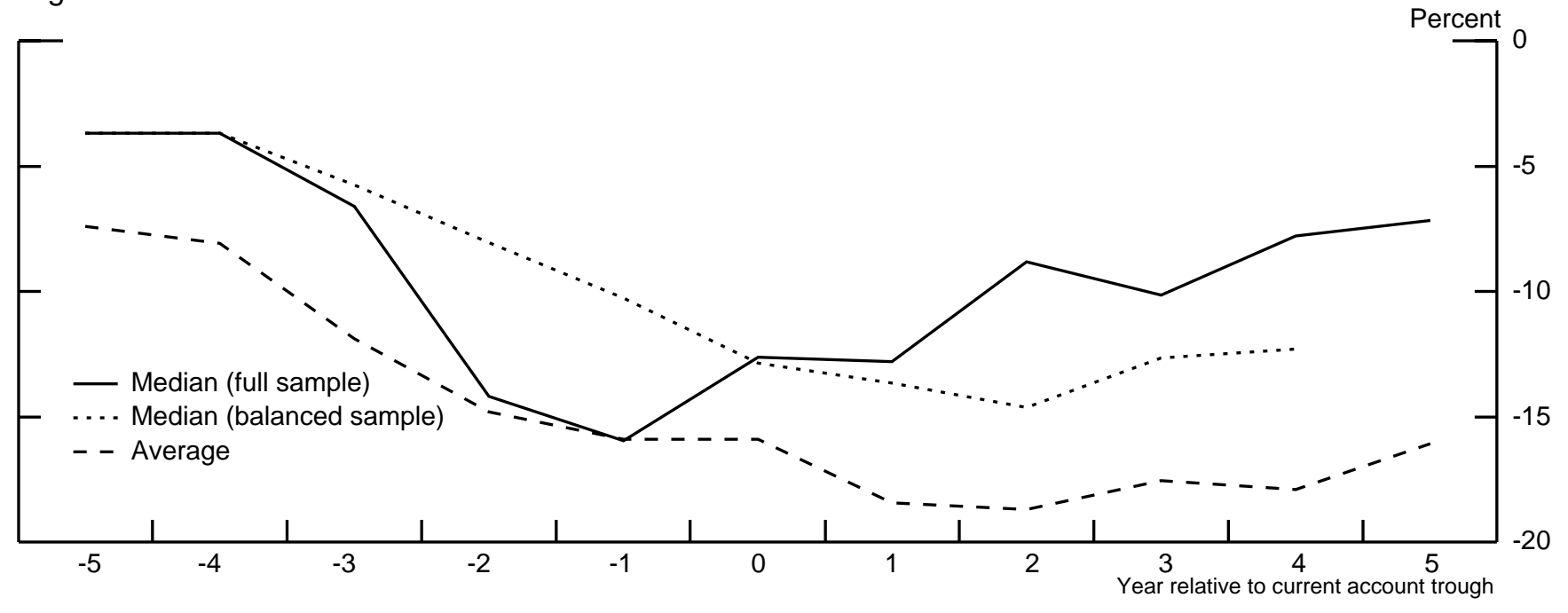

